\title{
Erratum: Mortality rates by occupation in Korea: a nationwide, 13-year follow up study
}

Lee HE, Kim HR, Chung YK, et al. Mortality rates by occupation in Korea: a nationwide, 13-year follow up study. Occup Environ Med 2016;doi:10.1136/oemed-2015-103192

This letter contains an error in the calendar year of follow-up of the cohort. The correct follow-up period was 1995-2009. The affected text has been corrected to now read:

Mortality was determined by matching death between July 1995 and December 2009 according to a nationwide registry of the Korea National Statistical Office.

The cohort data set was sent to the Korea National Statistical Office (KNSO) for matching deaths between July 1995 and December 2009.

Occup Environ Med 2016;73:496. doi:10.1136/oemed-2015-103192corr1
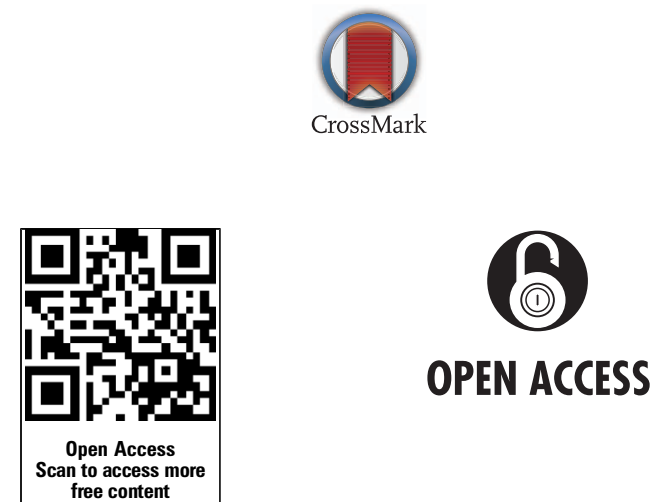

Open Access This is an Open Access article distributed in accordance with the Creative Commons Attribution Non Commercial (CC BY-NC 4.0) license, which permits others to distribute, remix, adapt, build upon this work non-commercially, and license their derivative works on different terms, provided the original work is properly cited and the use is noncommercial. See: http://creativecommons.org/licenses/by-nc/4.0/ 